Sigrid Aksnes Stykket

\title{
The Organic Birth and Growth of a Friendship and an Institutional Cooperation. Norway and EEA Grants Report
}

\section{Background: The Friendship}

In 1993 I was a Ph.D. student at the University of Oslo, taking some sparsely populated courses like "Dialect Variation in Old Norse in the $13^{\text {th }}$ Century" and "Old Norse Religious Poems". The latter was also attended by a Czech lady speaking Norwegian, and we talked together after the course, both amazed to find someone sharing our queer interests. That was the beginning of a lasting friendship with PhDr. Miluše Juříčková from the Faculty of Arts, Masaryk University, Brno. I soon invited her to Telemark to let her see where the trolls came from, and at Christmas time 1995 I went to visit in Brno. A 27-hour bus trip was something I had never experienced before; it was exhausting - and interesting, not least because I shared a seat with a young Slovak who taught me about both the Velvet Revolution and the Velvet Divorce. The split-up was so fresh and his pride in a new country so evident, but after the long bus ride I also met the feeling of bewildered disappointment in those who in a way felt left behind.

Brno in 1995 was really different from Norway, the Communist times still just over, some monuments still there, the shops still a lifetime away from what they are today. I sensed a certain inferiority complex towards Prague, as if everything was better, older, more valuable there. That was something I could not understand, I still remember the impression that the lavishly decorated churches made on a humble Protestant; I saw more churches in a week than I had seen my whole life in Norway, walking from one to the other to watch all their amazing Nativity Scenes, the betlémy. That trip in
1995 initiated a lasting love for Brno and the Czech Republic.

\section{Later: Erasmus cooperation}

After some years I was employed at Telemark University College, and when Miluše Juříčková now came to visit in $\mathrm{B} \varnothing$ we had lunch with my colleagues, and she made new acquaintances, and in time we found out about Erasmus exchange and found it a useful help to turn our friendship into something that could also bear fruit for students and colleagues. My colleagues learnt about Sigrid Undset and other Norwegian authors and their reception in Europe through Dr. Juříčková's lectures at Telemark University College, and students at Masaryk University learnt about Old Norse sagas and Norwegian folklore from me - among all the other things they got from visiting lecturers from Norway.

And then the students started coming from Masaryk to Telemark, not in big numbers, but one or two BA students each year, and some MA students spent a month or two in $B \varnothing$ to write part of their thesis there.

After Norwegian in Brno lost the little part they had of the Norwegian lecturer in Prague, I got the opportunity to be a three-week's stand-in there in March 2014, which gave an opportunity to learn more about the Czech Republic and the vast changes it has seen over the last twenty years, and to learn more about the Norwegian course contents. Pedagogical ideas have obviously changed over the years, like they have in Norway, and it turned out that we both 
have moved on from the one-sided emphasis on grammar rules and correct morphology to more oral production and actually filling an information gap instead of reproducing textbook sentences. We had many interesting discussions in the class, where relatively new students of Norwegian produced interesting thoughts in a fluent language.

I also got the chance to take part in the 40 years' anniversary of Norwegian courses at Masaryk in 2015, and it is easy to see that without these courses Czech bookshops and libraries would have looked different; a remarkable number of the students have translated Norwegian literature and made it available for the Czech public.

\section{The Norway and EEA Grants 2016}

And then last year there was an EEA call for grant applications. Those who have not tried it themselves could not possibly imagine how much effort it takes to write a good application. To coordinate and write it is a huge job, much too much for someone working full time in the first place. Associated professor Miluše Juříčková had some help from the administration; PhDr. Dana Spěváková should be given credit for her efforts, and Evy Beate Tveter and I did what we could from the Norwegian side, but the major job was Miluše Juříčková's. And it was rewarded. Two projects were granted, Language acquisition in the context of traditional and contemporary culture in Norway (NF-CZ07-ICP-4-330-2016), and Mobility project EEA Grants: Norwegian Literature: Location experience and European perspectives (NF-CZO7MOP-4-329-2016).

The first one, Language acquisition in the context of traditional and contemporary culture in Norway (NF-CZO7-ICP-4-330-2016), lasting from January to September 2016 consists of three major parts: a textbook, a special issue of Brünner Beiträge zur Germanistik und Nordistik (BBGN) and a workshop in Brno $13^{\text {th }}-16^{\text {th }}$ September 2016.

The textbook is intended for students at intermediate level of Norwegian and is an anthology of Norwegian texts in different genres: fiction, autobiography, blog, essay, textbook and more. Each text has an introduction in Norwegian and Czech, and explanations with questions to it at the end. Evy Beate Tveter, Sigrid Aksnes Stykket and Miluše Juř́čcková have found texts, discussed, rejected, found new ones, and written a few of the introductions, but the bulk of introductions have been written by students from Masaryk. And the timeconsuming task of talking to all the authors and publishing houses to get the rights to use all the texts without violating any copyrights has been Miluše Juř́čková's. She also had the responsibility for finding a good publishing house at a reasonable price.

The BBGN issue has contributions from employees at Telemark University College, (which in the meantime has fused with another university college and has now become University College of Southeast Norway) as well as some other Norwegians, which the reader can check by looking at the present table of contents. Here the contributors' contact has been mainly with the editor of BBGN.

The workshop in September 2016 will have four university lecturers and two students from University College of Southeast Norway together with students at all levels of Norwegian at Masaryk University, and the contents should mirror "traditional and contemporary culture" of different kinds: Norwegian folk music and arts, language history, folk dance, contemporary writers, Sami culture etc.

The latter project, Mobility project EEA Grants: Norwegian Literature: Location experience and European perspectives (NF-CZO7-MOP-4-329-2016), 
was carried out in spring 2016. The idea was to give the students an opportunity to learn more about the background of Norwegian authors they knew from their syllabus, and of the culture that brought them forth.

The students came by bus from Brno to $\mathrm{B} \varnothing$, and were of course introduced to the home of the most famous of Norwegian dramatists, Henrik Ibsen, Venstøp, Skien, where he was aptly contrasted to a young playwright, Fredrik Brattberg, who received the Ibsen Award 2012 for his drama Tilbakekomstene ("The returns"), currently staging in Brno. He talked about his philosophy of writing, and let us all get to know him a little better.

We also went to see Flatdal, where author Helga Flatland grew up. She is one of the younger Norwegian authors currently on the curriculum in both Norway and Europe with her Bli hvis du kan, reis hvis du må ("Stay if you can, go if you have to") translated into Czech by Miluše Juříčková. It was interesting to see all the parallels in her trilogy to her childhood landscape. At the Flatdal village we had PhDr. Stephen Walton as our guide, professor at our campus in $\mathrm{B} \varnothing$, who has also taught at the Summer School in Oslo for 25 years. He generously invited us all to his home where he had his large outdoor bathtub ready, together with a delicious rhubarb soup and a quiz.

To balance young author Helga Flatland with an older from the same area we went to learn more about Tarjei Vesaas, his background and his life. The Czech bus drivers told us they had been driving much worse roads and were not scared by the steep, narrow gravel road up to Vesås, so we had the opportunity to visit the remote farm up in the mountains where he grew up as the oldest son and heir of the farm. He was the $16^{\text {th }}$ generation in succession, but turned away from it to become a writer. The present owner, Tarjei Vesaas' nephew, and his wife took us to see "the Japan garden" which he has written about in one of his early works. This garden was now under reconstruction, and we were the first visitors to be taken there. From Vesås we drove to Midtbø, the home that Vesaas made for himself and his author wife Halldis Moren Vesaas, and for his two children, Olav and Guri, who both had come to receive us at the writer's home. We were invited into the sitting room where every item on the walls and in the room had its special story. Olav told many of them, supported by sister Guri. I guess none of the students hereafter will be able to read the opening pages of the novel The Birds without recalling the landscape of the hills of Midtbø.

We also saw the statue of Rev. M.B. Landstad (1802-1880), and we drove by bus some of the distances that he once covered by foot or by horse when he was collecting all the folk songs that enabled him to print the very first collection of Norske Folkeviser (Norwegian Folk Songs, 1851).

We also had a glimpse of the distant past in Telemark. We went to see the unique runic inscriptions in Bø Old Church (12 ${ }^{\text {th }}$ century). We went to visit Heddal Stave Church $\left(13^{\text {th }}\right.$ century), and to see an exact copy of the Viking ship Osebergskipet called Åsa, on the water ready for this summer's voyages. And we saw an exhibition of illustrations for Flateyarbók, an old Icelandic manuscript that is now being given a modern Norwegian translation and modern illustrations, but in a historic tradition. The illustrator Anders Kvåle Rue is a recognized artist who grew up in the same village as Helga Flatland. We met him at Nutheim, "the artists' hotel", where he also talked about his book Skjegg (Beard), a cultural history of the beard, and he told in such a manner that it would not surprise me if that book is translated into Czech in the near future.

For more recent history we went to an outdoor museum where Museum Director Finn Rønning explained about the Norwegian 
"husmannsvesen" ("cotter system") of the $18^{\text {th }}$ and $19^{\text {th }}$ centuries. As a bridge between the present and the past we met Vidar Sundstøl, a novelist writing historical fiction, who is best known for his Minnesota trilogy, but of more interest for us was his latest novel Djevelens giftering (The Devil's Wedding Ring, 2016), set in Telemark of past and present.

Being in Telemark, something would be missing if the students had not been presented to some parts of the history of World War II, especially about the heavy water sabotage at Rjukan. We went to Vemork, where the sabotage took place, and watched the BBC film about the sabotage, which made everybody really appreciate the effort it must have taken to get to a plant so difficult to reach, and to get away from it without being caught. Rjukan has received new attention this last year because of the sun mirror that has been built to give the inhabitants the chance to see the sun during the winter months, when it does not reach over the mountains surrounding the town. Rjukan together with Notodden was also recently appointed a UN Industrial Heritage Site.

It was a pleasure having the fourteen students from Brno here, and it will be interesting to see if anybody has got the inspiration to translate some of the authors they met or heard about. At the time of writing this the workshop in Brno is just ahead of us. Norwegian lecturers and students will meet the students at Masaryk again, we will have seminars on various Norwegian subjects, where the advanced students will translate to those who still need it, we will go on excursions together to Předklášteří, Lomnice, tasting Černa Horá beer, go to the opera together, and end up with a celebration of a successful project where we will see the Norwegian ambassador and the Head of Faculty among the guests.

And it is a bit strange to think that none of this would probably have happened if it had not been for an encounter at the university course on Old Norse religious poems in Oslo in 1993.

Sigrid Aksnes Stykket / Sigrid.A.Stykket@hit.no

University College of Southeast Norway, HSN-campus Bo, IKH-Hallvard Eikas plass 1, 3800 Bo I Telemark, Norway 